\title{
Generosity and Resilience: Transnational Activity among the Khmer of Norway
}

\author{
Gwynyth Jones Overland and Virak Yenn
}

\begin{abstract}
This article was submitted and accepted for publication in our recent volume on "Multiple Homes and Parallel Civil Societies: Refugee Diasporas and Transnationalism" guest edited by R. Cheran and Wolfram Zunzer. It was not included in that volume for reasons of space.
\end{abstract}

\begin{abstract}
The article reports on the pilot phase of an ongoing study of successfully rehabilitated Khmer refugees. Some of the most striking recoveries in this heavily traumatized group have taken place among those who have focused on contributing to the rebuilding of Cambodia. The article explores this collective and individual transnational generosity both generally, as an aspect of survivor resilience, and specifically by following one process. Why do Khmer refugees want to build a school and what does it mean to them? How does their transnational generosity relate to the resilience of Khmer refugees? Their own explanations are founded in their religion.
\end{abstract}

\section{Résumé}

Cet article est un compte rendu sur la phase pilote d'une étude en cours sur des réfugiés khmers réhabilités avec succès. Certains des rétablissements les plus frappants dans ce groupe fortement traumatisé sont survenus parmi ceux qui se sont évertués d'apporter leurs contributions à la reconstruction du Cambodge. Cet article explore cette générosité transnationale collective et individuelle tant sur le plan général, dans son aspect de l'endurance du survivant, que sur un plan plus spécifique d'un processus donné. Pourquoi les réfugiés khmers veulent-ils construire une école et qu'est-ce que cela signifie pour eux? De quelle façon leur générosité transnationale se rapporte-t-elle à l'endurance du réfugié khmer? Leurs propres explications trouvent leurs fondements dans leur religion.

\section{Introduction}

The Khmer population in Norway numbers about three hundred persons - those who came as refugees from the camps along the Thai border, their children, and grandchildren. They were all settled in the same area in the late 1980s and almost all remain there. Khmer refugees are arguably the most traumatized refugees to have been resettled in Scandinavia, yet many have demonstrated a striking resilience. Marriages take place, children are born, and the parent generation, who balanced for a decade or so in the 1970s and 1980s on the edge of human experience, seem to have found a kind of peace. Second-generation Cambodians also display a striking buoyancy and creativity (see photo: flying boy). In this population there are many who have rehabilitated themselves: they appear to have rewon the ability to lead a normal life. How did this happen?

In the final analysis, the individual's resilience - the ability to "bounce back" or regain form after great strain may make the difference between integration and disintegration for survivors. ${ }^{1}$ Resilience is an extensive and growing field of study; a Web search for the term produced 332,000 hits, including a current definition: "ability to adapt well to unexpected changes and events." 2 Research indicates various factors that may play a role in the resilience of refugee survivors who are successfully rehabilitated. A sense of coherence, work or meaningful activity, the continuity of cultural practices, religious beliefs, social 
network, family coherence, and "steeling" through earlier traumatic experience are some examples. ${ }^{3}$ Survivors' perspectives on their own recoveries are more uncommon, however. What do they think has contributed most to their survival after experiences known to destroy lives?

The article reports on the pilot phase of an ongoing study of successfully rehabilitated refugee survivors of war, concentration camps, and human rights abuses, based on an analysis of their biographical narratives. In recent years the focus of research on survival has slowly shifted from "misery" to "mastering" - from the study of problems to the study of resilient behaviour, from risk factors to protective factors, and from therapy to efforts to strengthen competency. ${ }^{4}$ The final aim of the study will be to develop hypotheses, grounded in the narratives, that may be of use for the substantive area of sociological inquiry constituted by patient care and psychosocial work with this vulnerable group. Mapping agents' methods for survival and triangulating their narratives, their interpretations, and social theory are hoped to contribute to new ways of working with refugees as clients and patients.

This is a qualitative study, dealing as it does with biographical memories, thoughts, and feelings. The methodological basis is dialogue and participant observation among a population of Cambodian refugees who have made a remarkable recovery against all odds and in spite of a heavy load of traumatic experiences. In particular, a dialogue has continued over a period of ten years between the researcher and a Khmer gatekeeper who has been leader both of the Cambodian Society and of the Khmer Buddhist Society in this period. Secondary sources include reports and letters from the Khmer societies and field notes. As a consequence of culturally founded explanations offered by the informants, theoretical perspectives from Buddhist philosophy / psychology are explored and viewed in the light of sociological constructivism.

The first factor emphasized by Khmer survivors in Norway as useful for them has been their contact with the home country, including the giving of charitable donations to worthy causes. "The plate goes round: Norwegians give 10 dollars; Cambodians give 100."5 Resilience appeared to be correlated with this generosity.

The article therefore charts the forms and extent of generosity and other altruistic behaviour among Khmer in Norway and follows one sample process: the building of a school in southeastern Cambodia. Why do Khmer refugees want to build a school and what does it mean for them? What forms of transnational generosity actually go on? How does their transnational generosity relate to the resilience of Khmer refugees?

\section{Background: The Khmer Diaspora}

In the Thai border camps, where the Norwegian Khmer lived for an average of eight years, a study of mental health status was carried out in 1990. At Site Two, one of the largest camps, 993 adults were interviewed about traumatic experiences and symptoms, using the Harvard Trauma Questionnaire and the Hopkins Symptom Checklist-25. Of the 993 interviewed, 55 per cent had scores correlating with major depression and hopelessness; 70.9 per cent had recurrent memories and nightmares. In conclusion, Mollica and his colleagues appealed to the powers that be to address the mental health needs of this population after repatriation or resettlement, warning that such exposures may produce serious long-term social and psychological effects. ${ }^{6}$

In resettlement countries, reports vary as to how Khmer survivors have fared. In Canada, for example, about twenty thousand Cambodians arrived in the 1980s. According to one report they did not benefit from government service and support or from post-trauma treatment and encountered profound difficulties because of the lack of a unifying and encompassing structure after their traumatic experiences. ${ }^{7}$ In the US, it is "estimated that virtually all victims of the Khmer Rouge period suffer from post traumatic stress disorder." ${ }^{8}$ In spite of having been vetted for mental health prior to being granted residence, corresponding populations in the US showed an incidence of mental suffering six times higher than the national average. ${ }^{9}$ Interestingly, the Scandinavian countries followed the consciously humane policy of opting for UNHCR's "20-or-more" plan for refugees with special medical needs. ${ }^{10}$ With this point of departure it could be assumed that a population's needs would be greater still.

In Finland, another Scandinavian country, Khmer numbered about 150 in the late 1980s.

They never developed the critical mass to have a very vibrant community.... Many have had very serious problems of integration to work through, possibly because of the lack of supports and the desperate state of the society from which they came. ${ }^{11}$

The group that arrived in Norway was about the same size as the Finnish Cambodian population (about two hundred persons). The Norwegian Cambodians received no particular attention from the health services when they arrived. All of the adult informants had such traumatic exposures as described in the international manual used by therapists to diagnose post-traumatic stress disorder (PTSD):

1. The person experienced, witnessed, or was confronted with an event or events that involved actual or threat- 
ened death or serious injury, or a threat to the physical integrity of self or others.

2. The person's response involved intense fear, helplessness, or horror. ${ }^{12}$

Some have been less successful than others. The present sample, however, consists of persons who (1) were exposed to the kind of traumatic events mentioned above, yet (2) didn't develop the disability. They are resilient individuals - people who acknowledge that they have won over a traumatic past. In the following they will be referred to as Norwegian Khmer, because they constitute the majority.

\section{Transnational Generosity Practiced by This Group}

The Khmer Buddhist Association (KBA) in Norway has kept records of its activities for more than ten years. They reported that they began to collect money for good causes after the first visit (since 1975) of a group of Norwegian Khmer to Cambodia in 1993. They were shocked by conditions there and readily collected US $\$ 10,000$. They have since contributed to the building of temples, roads, and schools in three main communities to which Khmer in Norway are connected by family or birth. Some Norwegian Khmer live on disability benefits, but still manage to give generously by collecting empty bottles, acorns, strawberries. They save the money to build small houses, "enough for a family of 3-4." Some also support the studies of young monks - "it is their only way to get an education," reported the KBA.

A recent project began with the visit of a monk. There are no Cambodian monks in Norway and no temple. On Khmer New Year 2003 the KBA had managed to bring a Khmer monk to Norway. With him he had a letter from his village asking for help to build a junior high school or collège: they had a primary school, but five hundred to six hundred pupils were then at risk of stopping their education because of the distance to the nearest secondary school.

At a religious ceremony a few days later, many Khmer families gathered to hear the monk at a local gym. They were dressed in their finest and had with them food and children of all ages. After an orientation about the schoolbuilding project there was a collection and water blessing.

A table was covered with silk and flowers, incense, candles, a bowl of water and a bunch of twigs. Each person rose from the floor and went up to lay a donation on a golden platter. The monk blessed them by shaking a few drops of water on their heads. Teenagers in training clothes were held by the arms and their hands lifted to make a sompeah amid laughter and teasing. ${ }^{13}$
The KBA sent the following explanation and request to the local Norwegian Cambodian Friendship Association, a voluntary organization with both Norwegian and Khmer members:

Like other parts of the country, Phum Puon district was ruined after 30 years of war. The reconstruction of society in relation to socio-cultural factors is very slow and dependent on contributions from Cambodians abroad.

Phum Puon is a typical rice-growing village in Cambodia. Production materials and methods are still primitive with the result that the living standard is low. The people live without electricity and running water. Since 1979 the people have sent their children to the Buddhist temple to study. Thanks to support from exile Khmer, a primary school was built in 1999 . Because of lack of means, the people cannot afford to give their children secondary education.

Establishment of a Cambodian-Norwegian junior high school will be a great gift from the Norwegian people that will help a new generation of Cambodians to obtain an education. ${ }^{14}$

The Friendship Association chose to support the schoolbuilding project and to apply for funding from NORAD, the Norwegian aid program. NORAD requires that a minimum of 10 per cent of the amount solicited be collected by fundraising.

In addition to collections among the Khmer community, the KBA immediately set to work at a local factory. After less than a month of tenacious fundraising, they reported modestly that they hadn't done as well as hoped, but that they had still collected US $\$ 3,000$. This was almost 10 per cent of the required sum, and in September an application was sent to NORAD. Through the transnational network, Khmer professionals at Save the Children Norway (SCN) in Cambodia declared themselves willing to monitor the building in their spare time. SCN's school-building policy emphasizes civil empowerment: participation at the grassroots level, gender participation, and accountability are core values for NORAD, and support was granted. The school building will soon be completed.

\section{Why Should Khmer Refugees Want to Build a School and What Does It Mean for Them?}

Why do war refugees wish to use fairly large amounts of modest resources of money, time, and energy to build houses, roads, temples, and schools thousands of miles away? How do they explain it?

INTERVIEWER: So you give to schools, temples, roads, and houses - why do you think people do this? 
RESPONDENT: Well, we cultivate it. In the association we talk about it, about trying to help our homeland - both in fellowship and individually.... We have tried to cultivate a sense of generosity to our homeland. If we do good deeds, we hope we'll have a good life. ${ }^{15}$

This is a common understanding found in Buddhism, and viewed in this perspective appears to be a reference to Khmer Buddhism. A form of Theraváda, Khmer Buddhism is an endemic religion, a kind of minimal religious practice that everyone participates in and that helps bind a people together. Saturated with associative meanings, with shared cultural imagery, it is not "the frozen artefactual stuff of museum displays and cultural performances." ${ }^{16}$ In all forms of Buddhism, generosity is a cardinal virtue, the first of the six paramitas or moral perfections - perhaps a natural place to begin if one is committed to self-improvement in a Buddhist cultural context. "The essence of generosity is giving without any attachment or expectations, without any thought of receiving some thing in return." ${ }^{17}$ The practice of generous deeds such as donating to the temple, giving alms to monks - even buying freedom for a caged sparrow - are everyday ways of earning merit for the Cambodian Buddhist. Accumulating merit in the endemic belief system is the way to salvation: "In the narrow way of Hináyána it is not expected that everyone will arrive at Nirvána, it is only a question of amassing merit, which can take thousands of years." 18

Acts of generosity and loving kindness are also "skilful means" (punna), conducive to the growth of wholesome states. ${ }^{19}$ Through effectively turning the attention of the practitioner from ego to alter, these acts are believed to be beneficial for the practitioner. the Dalai Lama writes: "Foolish selfish people are always thinking of themselves, and the result is negative. Wise selfish people think of others, help others as much as they can, and the result is that they too receive benefit." 20

The Cambodian patriarch Mahá Ghosananda writes, "Great beings maintain their mental balance by giving preference to the welfare of others, working to alleviate the suffering of others, feeling joy for the successes of others, and treating all beings equally." 21 This monk has made a life's work of reminding Cambodians of their Buddhist heritage. He expresses faith in Cambodia's ability to heal itself, "reminding us that Buddhism was alive in us and that we could call upon the sweetness and depth of the tradition." ${ }^{22}$ Ghosananda has made several trips to Norway at his own initiative, where "Travellers in the arrival hall were surprised to see a tiny man with bare feet and orange robes surrounded by a crowd of Norwegian Khmer lying flat on their faces." 23
Ghosananda's description of the merits of loving kindness resembles in some ways a self-help handbook for rehabilitation:

Those who practice loving kindness sleep well. They have no bad dreams. They wake up happy. They can focus their minds quickly. Their minds are clear and calm. They have no nervousness. No fire, poisons or weapons will harm them.... They are loved by all sentient beings. Their complexion becomes clear. They will attain nirvana. ${ }^{24}$

\section{How does their transnational generosity relate to the resilience of Khmer refugees?}

If we do good deeds, we hope we'll have a good life.

Khmer in Norway appear to subscribe to the Buddhist tenet that good deeds relieve suffering and generate happiness. A strongly motivated subgroup of Khmer in Norway has striven to keep Buddhism and its endemic value system alive in the community. They explain that it is 90 per cent due to the driving force of a few enthusiasts that the attempt has to an extent succeeded. A working hypothesis suggests that Khmer in Norway find their religious guidelines a useful self-therapy: an endemic religious belief in the benefits of good deeds and generosity is so deeply ingrained that it actually appears to bring the peace that is promised.

Giving is explained by Norwegian Khmer as a conscious strategy for improving their own feeling of self-worth. The school-building process, beginning with the invitation to the monk and the monk's "mission" on behalf of the needy children in his own village, performed in the setting of a religious ceremony, firmly established the connection between generosity and traditional religious values for the participants. In simple terms, Norwegian Khmer explain generosity with religion, and religion explains the links between skilful means - acts of generosity, loving kindness, and compassion - and rehabilitation, healing, or rewinning a feeling of self-worth. The diagnosis and prescription of Buddhist philosophy and psychology, which predicate suffering and the way out of suffering, constitute the logic of the model.

In a psychological perspective, culture may buffer its members from the impact of stressful experience "by furnishing social support, providing identities by means of norms and values, and supplying a shared vision of the future": cultural stories, rituals and legends, the relation to the spiritual realm, and religion itself are important mechanisms. ${ }^{25}$ 
From a sociological perspective, the originators of "the social construction of reality," Berger and Luckman, write, "Individuals who have acquired stable orientations possess an effective panacea against existential threats to their selfperception. They regard themselves as people with an undoubted identity." 26 The persistent attempts of Khmer in Norway to cleave to their religion despite the lack of the usual basic materials - a monk, a place, a book of teachings - seem to be an example of this

In the wake of the Second World War the Russian American sociologist Sorokin established the Center for the Study of Creative Altrusim at Harvard. After several years' intensive study, he concluded that altruism can stop aggressivity, turn inimical relations to friendly ones, beget love, and in general hinder war and promote peace - provided we know how to produce it. Altruism may evolve by cultural evolution and transmission: parents can transmit their traits to the next generation by teaching. ${ }^{27}$ The tasks children are assigned are also seen to have consequences for the development of interpersonal behaviour. Children who care for small siblings, as is common in many traditional societies, develop more nurturant behaviour, ${ }^{28}$ a possible precondition for altruism.

If we are to accept Sorokin's research, culturally transmitted altruism has a potential for affecting life quality. ${ }^{29}$ He contends that only when a religion or other ideology is so deeply rooted in the human mind that it is consistently practiced, may it become a driving force. ${ }^{30}$ Khmer Buddhism may be an example.

Using the gatekeeper as key informant rather than going out with a broad enquiry has been a methodological limitation of this pilot study. This has been imposed by an ethical consideration - a wish to hold back on the exploration of trauma stories in a non-clinical setting. The work with the gatekeeper suggests however that it may be possible to speak openly about recovery without digging into the past, and that acknowledging the achievement of informants may produce a positive action research effect.

The generosity of Norwegian Khmer is a small example of a global pattern. The International Organization for Migration (IOM) points out that remittances sent home by international migrants to developing countries in 2003 through official channels alone was US\$93 billion - a sum considerably greater than the total development assistance sent by rich countries. It is assumed that unofficial remittances are even greater. "In many developing countries, remittances represent the most important source of foreign exchange." 31

There is a soteriological motive in Khmer generosity: it harvests merit and merit is the way to salvation. This motive does not pretend to explain the generosity of other refugee groups, but may suggest one factor that deserves attention and further research in regard to the motivation for this major cash flow in the world economy. As is known, generosity and caring for those less fortunate are also virtues both in Islam and in Christianity.

This limited research is innocent of the great findings of resilience research, and presents a simple finding from a small sample. From the Norwegian Khmer experience it may be possible to draw the implication for psychosocial work that, for some vulnerable groups, giving the space for, acknowledging, and respecting refugees' religious practices may have a regenerative potential.

\section{Notes}

1. Michael Rutter, "Psychosocial Resilience and Protective Mechanisms," in Risk and Protective Factors in the Development of Psychopathology, ed. J. Rolf (New York: Cambridge University Press, 1990); Charles Watters, "Emerging Paradigms in the Mental Health Care of Refugees," Social Science and Medicine 52 (2001); Aaron Antonovsky, Unravelling the Mystery of Health (San Francisco: Jossey-Bass, 1987); Helen Christie and Trine Waaktaar, Styrk sterke sider: Håndbok i resiliencegrupper for barn med psykososiale belastninger (Oslo: Kommuneforlaget, 2000).

2. American Psychological Association, <http://helping.apa. org/resilience/war/html> (accessed February 10, 2004).

3. Antonovsky; Birgit Lie and Nora Sveaass, "Family, Activity, and Stress Reactions in Exile," Community, Work and Family 7, no. 3 (2004): 327-350; Helen Christie, "The Perspective of Resilience in the Treatment of Refugees" (paper, Nordic Conference for Psychotherapists Working with Traumatised Refugees, Tromsø, 1998); Edvard Hauff, "Vietnamesiske flyktninger i Norge - noen refleksjoner i etterkant av et forskningsprosjekt," Linjer 2 (1999) [note: Linjer is published by the Psychosocial Center for Refugees, University of Oslo]; Gwynyth Øverland, "Kulturell kontinuitet og personlig identitet blant overlevere fra den kampucheanske holocausten," Linjer 2 (1999).

4. Anne Borge, Resiliens - risiko og sunn utvikling (Oslo: Gyldendal, 2003):35, my translation.

5. Field note, April 18, 2004.

6. Richard Mollica et al., "The Effect of Trauma and Confinement on Functional Health and Mental Health Status of Cambodians Living in the Thailand-Cambodia Border Camps," Journal of the American Medical Association 270, no.5 (1993): 581-586.

7. Janet McLellan, Many Petals of the Lotus: Five Asian Buddhist Communitise in Toronto (Toronto: University of Toronto Press, 1999), 134.

8. Seanglim Bit, The Warrior Heritage (El Cerrito, CA: Seanglim Bit, 1991), 114.

9. K. Meinhardt, "Contributions of Epidemiological Surveys to Planning," in Mental Health of Immigrants and Refugees (Austin: University of Texas Press, 1992), 45. 
10. United Nations High Commissioner for Refugees, $<$ http://www.unhcr.org.uk/resettlement $>$ (accessed November 24, 2004).

11. Kathleen Valtonen, personal communication, 2004.

12. DSM-IV: Diagnostical and Statistical Manual of Mental Disorders (Washington: American Psychiatric Association, 1995), 439.

13. Field note (Lillesand, June 1, 2003).

14. Letter from Khmer Buddhist Association, June 27, 2003 (translated by G. Overland).

15. Interview with Khmer Buddhist Association, Kristiansand, Norway, July 17, 2003.

16. C. Keyes, Laurel Kendall, and Helen Hardacre, eds., Asian Visions of Authority: Religion and the Modern States of East and Southeast Asia (Honolulu: University of Hawaii, 1994), 12.

17. Traleg Kyabgon, Mind at Ease: Self-liberation through Mahamudra Meditation (Boston: Shambala, 2003), 51.

18. Interview with an abbot, Takeo, Cambodia, January 15, 1998.

19. Peter Harvey, An Introduction to Buddhism: Teachings, History and Practices (Cambridge: Cambridge University Press, 1990), 42.

20. Sidney Piburn, ed. The Dalai Lama: A Policy of Kindness. An Anthology of Writing By and About the Dalai Lama (Ithaca: Snow Lion, 1990), 58.

21. Maha Ghosananda, Step by Step (Berkeley: Parallax, 1992), 61.

22. Dith Pran, ibid., xi.

23. Field note (Kristiansand, 1997).

24. Ghosananda.

25. Martin de Vries, "Trauma in a Cultural Perspective" in Traumatic Stress: The Effects of Overwhelming Experience on Mind and Body, ed. Martin de Vries (London: Guilford, 1996), 400.

26. Peter Berger and Thomas Luckman, Modernity, Pluralism and the Crisis of Meaning (Gutersloh: Bertelsmann, 1995), 5.

27. William Durham, "The Role of Culture in the Evolution of Altruism," < http://www.altruisticlove.org/docs/durham> (accessed July 7, 2004).

28. Barbara Rogoff, The Cultural Nature of Human Development (Oxford: Oxford University Press, 2003), 75, 125.

29. Pitirim Sorokin, On the Practice of Sociology (Chicago: University of Chicago Press, 1998), 306.

30. Pitirim Sorokin, Menneskehetens Gjenreisning [The Reconstruction of Humanity] (Oslo: Norli, 1953), 64. (The quotation is translated by G. Overland.)

31. Brunson McKinley, "Migrant Remittances: A Key Development Resource," IOM News, September 2004, 3.
Gwynyth Overland is senior consultant sociologist at Psychosocial Team for Refugees / Regional Trauma Centre in southern Norway. After a comparative study on Cambodians in Norway and Cambodia ("Culture and Survival: The Continuity of Cultural Practices among Cambodian Refugees in Norway") she has continued to research and write about aspects of refugee identity in Norwegian and English.

Co-author Virak Yenn is a Cambodian former teacher and survivor of the Khmer Rouge atrocities. He is active in a range of voluntary activities for the benefit of Cambodians both in Cambodia and in Norway. 